\title{
Antibiotic resistance profiles of environmental isolates from Mhlathuze River, KwaZulu-Natal (RSA)
}

\author{
J Lin ${ }^{1 *}$, PT Biyela ${ }^{2}$ and T Puckree ${ }^{3}$ \\ ${ }^{1}$ Department of Microbiology, University of Durban Westville, Private Bag X54001, Durban 4000, South Africa \\ ${ }^{2}$ Department of Biochemistry and Microbiology, University of Zululand, Private Bag X1001, KwaDlangezwa, 3886, South Africa \\ ${ }^{3}$ Department of Physiotherapy, University of Durban Westville, Private Bag X 54001, Durban 4001, South Africa
}

\begin{abstract}
One hundred and thirteen enteric bacteria were isolated from the Mhlathuze River during February 2001 to January 2002. The antibiotic resistance patterns (ARPs) of these identified isolates showed that $94.7 \%$ were resistant to at least one class of antibiotic while $75.2 \%$ were multi-resistant. All isolates were sensitive to gentamicin. The levels of resistance exhibited by isolates to specific antibiotics are as follows: penicillin, $72.6 \%$; rifampicin, $69.2 \%$; novobiocin, $52.1 \%$; ampicillin, $43.6 \%$ and cephalothin, $28.2 \%$. The antibiotic resistance gene pool especially that for $\beta$-lactamase is likely to be widely available in the environment. The ARPs for $E$. coli and non-E. coli groups were very similar. The enteric bacteria isolated from downstream, which is a mainly urban and industrial area, were more resistant to several antibiotics than those from upstream which is predominantly rural. The results suggest that environmental, industrial and/or human activities impact on the level of antibiotic resistance in the environment. The strong correlation $(\mathrm{r}=0.97)$ between the ARPs of the clinical and the environmental isolates may suggest a link between diarrhoeal incidence and the water quality in the region. It is thus imperative that the determination of antibiotic susceptibility/resistance patterns of isolated microbes is a part of the microbial monitoring process of the water.
\end{abstract}

Keywords: antibiotic resistance profile, Mhlathuze, environmental, Enterobacteriaceae

\section{Introduction}

The increase of faecal pollution in source water is a problem in developing as well as in developed countries (American Society for Microbiology (ASM) Colloquium Report, 1999). Water-borne bacterial pathogens such as E. coli 0157 , Salmonella spp., Shigella spp. and Vibrio cholerae can lead to diarrhoeal outbreaks that may have serious medical and economic implications (WHO, 2000; WHO, 1996). This problem is further compounded by the increasing incidence of pathogens with antibiotic and/or drug resistance (DePaola et al., 1995; Ogan and Nwiika, 1993). Exposure to environmental pollutants and changes in nutrient composition may lead to selective pressures favoring certain organisms or genotypes. Recent studies demonstrated positive correlations between industrial pollution and the spatial distribution of antibiotic resistance (Goñi-Urriza et al., 2000; McArthur and Tuckfield, 2000). Heavy use of antibiotics for medical and veterinary purposes (Balagué and García Véscovi, 2001; White et al., 2000) as well as the domestic and agricultural use of pesticides and related compounds (Balagué and García Véscovi, 2001) caused significant antibiotic contamination of the natural environment and consequent development of resistance in communities. Antibiotic and drug resistance in medicine generates significant health and economic impacts (ASM Colloquium Report, 1999).

A recent study (Ash et al., 2002) showed that several rivers in the United States of America have become a major reservoir for antibiotic-resistant microbes. With global travel and widespread commerce, drug- and antibiotic-resistant microbes can spread to all parts of the world.

\footnotetext{
* To whom all correspondence should be addressed.

莤 +2731 2044407; fax: +2731 2044809;

e-mail: jlin@pixie.udw.ac.za or lin2000j@yahoo.com

Received 12 May 2003; accepted in revised form 8 October 2003.
}

Similar to that for antibiotics, heavy metal contamination is also a severe environmental problem due to the increase in human and industrial activities (ASM Colloquium Report, 1999). Heavy metals such as lead, mercury, cadmium and nickel are metabolically poisonous at low concentrations. They inhibit the activities of certain enzymes involved in the metabolic process (Midigan et al., 2003). At high concentrations these metals form unspecific complex compounds in the micro-organism, which leads to toxic effects (Nies, 1999). Bacterial accumulation of and resistance to toxic heavy metals is a widespread phenomenon. The mechanisms of heavy metal resistance have been reported to enhance the antibiotic resistance ability of microorganisms (Davidson, 1999; Edlund et al., 1996).

The Mhlathuze catchment sustains various agricultural and industrial communities. This water system also serves as a main source of water to the large rural population which resides in this region (Steyl et al., 2000). The results from monitoring physicochemical and microbiological quality of the Mhlathuze River (Lin et al., 2004a; Bezuidenhout et al., 2002) indicated a high contamination of faecal coliform and heavy metals in this water system. The industrial and intensive farming activities in this region might also contribute to the selection of antibiotic resistance genes in bacteria that colonize humans and animals. Therefore in this study we focused on the level of antibiotic and metal resistances of enteric bacteria in this water system.

\section{Materials and methods}

\section{Isolation of bacteria}

All water samples were collected every two weeks from 5 different sites namely KwaDlangezwa, Dlangubo, Richards Bay estuary, Mhlathuze pumping station and Felixton, along the Mhlathuze 
River from March 2001 to January 2002 and analysed as described in the previous report (Lin et al., 2004a).

Single colonies of bacteria were randomly selected from nutrient agar, mEndo and $\mathrm{mFC}$ plates based on the morphology. These were subsequently isolated in pure form. Single colonies from the heavy metal were also isolated for identification and analysis.

\section{Identification of bacteria}

The isolates were then identified using Gram stain and biochemical reactions (Standard Methods, 1998) and confirmed by API strips applied according to the manufacturer's instructions (BioMerieux, France). Only members of the Enterobacteriaceae family and Pseudomonas/Aeromonas spp. were used for antibiotic resistance tests. All isolates from heavy-metal nutrient agar were used for antibiotic resistance tests.

\section{Effects of heavy metals on microbial growth}

Equal volumes $(0.1 \mathrm{~m} \ell)$ of water samples from each different site were spread onto nutrient agar plates or inoculated onto nutrient broth containing various concentrations $\left(0\right.$ to $\left.0.5 \mathrm{mg} \cdot \ell^{-1}\right)$ of different heavy metals. The mixture was then incubated at $37^{\circ} \mathrm{C}$ overnight. The growth of the microbes was measured by determining the optical density at $600 \mathrm{~nm}$ and confirmed with the results from the nutrient agar plates.

\section{Antibiotic sensitivity tests}

The disc diffusion method (NCCLS, 2000) was used to determine antibiotic sensitivity of the isolates. Overnight broth cultures were

\begin{tabular}{|c|c|c|}
\hline \multicolumn{3}{|c|}{$\begin{array}{l}\text { TABLE } 1 \\
\text { The classes and concentrations of antibiotics used in } \\
\text { the study }\end{array}$} \\
\hline Class & Antibiotic used & Quantity \\
\hline Fluoroquinolones & Ciprofloxazin & $5 \mu \mathrm{g}$ \\
\hline Phenicols & Chloramphenicol & $30 \mu \mathrm{g}$ \\
\hline Aminocoumarin & Novobiocin & $30 \mu \mathrm{g}$ \\
\hline Folate Inhibitors & Co-trimoxazole & $1.25 \mu \mathrm{g}$ \\
\hline Ansamycins & Rifampicin & $5 \mu \mathrm{g}$ \\
\hline Quinolones & Nalidixic acid & $30 \mu \mathrm{g}$ \\
\hline Cephalosporin & $\begin{array}{l}\text { Cefuroxime; Cephalothin; } \\
\text { Cefotaxime; Cefoxitin }\end{array}$ & $30 \mu \mathrm{g}$ \\
\hline Aminoglycosides & Streptomycin; gentamicin & $10 \mu \mathrm{g}$ \\
\hline Tetracyclines & Tetracycline & $30 \mu \mathrm{g}$ \\
\hline$\beta$-lactamase & Ampicillin; Penicillin & $10 \mu \mathrm{g} ; 10 \mathrm{U}$ \\
\hline
\end{tabular}
nutrient agar plates which were infused with high concentrations of

spread on Hilton-Mueller agar plates. The plates were dried at room temperature for $2 \mathrm{~h}$. Antibiotic discs were placed at equi-distances. The plates were incubated for $24 \mathrm{~h}$ at $37^{\circ} \mathrm{C}$ and organisms were classified as sensitive, intermediate or resistant, based on the NCCLS standards.

A total of 15 antibiotics used in this study can be classified into 10 different classes as shown in Table 1 .

\section{Statistical analysis}

All percentage data were arcsine transformed before analysis. Paired t-tests (Wilkinson, 1988) were used to examine the statistical significance between different species. Pearson's correlation coefficient (r) was used to represent the relationship between the clinical isolates and the Enterobacteriaceae isolates.

\section{Results}

\section{Antibiotic resistance levels}

From February 2001 to January 2002, a total of 113 enteric bacteria were isolated and identified as follows: 42 E. coli; 27 Citrobacter freundii; 23 Klebsiella spp.; 11 Enterobacter spp.; 7 Serratia marcesens and 3 Proteus spp.

All isolates were sensitive to gentamicin. These isolates were also sensitive to ciprofloxacin with the exception of one Pseudomonas isolate. This Pseudomonas isolate showed the highest level of resistance to tested antibiotics (12 out of 15). These antibiotics included all 10 classes tested, excluding the aminoglycosides. Cefotaxime inhibited the growth of all enteric bacteria isolates with the exception of one Klebsiela and one Enterbacter isolate. All S. marcesens isolates were resistant to rifampicin. The proportional resistance (\%) of total isolates of Enterobacteriaceae from the Mhlathuze River to different classes of antibiotics is shown in Table $2.94 .7 \%$ of enteric bacterial isolates were resistant to at least one class and $75.2 \%$ to two or more classes of antibiotics. Four enteric bacterial isolates, consisting of $1 \mathrm{E}$. coli and 3 S. marcesens, were resistant to 8 out of 15 different antibiotics tested ( 6 or 7 classes of antibiotics). Amongst non- $E$. coli isolates, only two Enterobacter isolates were sensitive to all antibiotics. Other genera (Klebsiela spp., S. marcesens, Serratia spp., C. freundii and Proteus spp.) were resistant to at least one antibiotic. Microbes that were resistant to three classes of antibiotics were the most common.

Table 3 shows the percentage of total and site-specific enteric bacterial isolates resistant to specific antibiotics during the study period. ARPs of E. coli and non- $E$. coli isolates are also shown in Table 3. The levels of resistance exhibited by isolates to specific antibiotics are as follows: penicillin, $72.6 \%$; rifampicin, $69.2 \%$; novobiocin, 52.1\%; ampicillin, $43.6 \%$ and cephalothin, $28.2 \%$. The ARPs between $E$. coli and non-E. coli groups were very similar. The non- $E$. coli group showed higher resistance against nalidixic acid, novobiocin, cefuroxin and cefotaxime than E. coli isolates.

Proportional resistance (\%) of total isolates of Enterobacteriaceae from Mhlathuze River to different classes of antibiotics

\begin{tabular}{|l|c|c|c|c|c|c|c|c|}
\hline No. of Antibiotic & $\mathbf{0}(\%)$ & $\mathbf{1 ( \% )}$ & $\mathbf{2 ( \% )}$ & $\mathbf{3 ( \% )}$ & $\mathbf{4 ( \% )}$ & $\mathbf{5 ( \% )}$ & $\mathbf{6 ( \% )}$ & $\mathbf{7 ( \% )}$ \\
\hline Total Enterobacteriaceae isolates & 5.3 & 19.5 & 22.1 & 32.7 & 18.6 & 6.2 & 2.7 & 1.8 \\
E. coli & 9.5 & 19.0 & 19.0 & 35.7 & 7.1 & 7.1 & 0.0 & 2.4 \\
Non-E. coli & 2.8 & 19.7 & 23.9 & 31.0 & 25.4 & 5.6 & 4.2 & 1.4 \\
\hline
\end{tabular}

\section{Comparison of ARPs from different sites}

ARPs for the above-mentioned antibiotics, which were commonly resisted by the enteric bacteria were generally similar 
TABLE 3

Percentage of total and site-specific enteric bacterial isolates resistant to specific antibiotics during the period of February 2001 to January 2002

\begin{tabular}{|c|c|c|c|c|c|c|c|c|c|c|c|c|c|}
\hline Antibiotic & A & $\mathbf{P}$ & $\mathbf{T}$ & $\mathbf{s}$ & CXM & NA & RIP & KF & TS & C & СТX & FOX & NO \\
\hline Total & 43.6 & 72.6 & 9.4 & 16.2 & 5.1 & 6.8 & 67.0 & 26.6 & 10.3 & 4.3 & 1.7 & 6.0 & 52.1 \\
\hline E. coli & 46.5 & 69.8 & 11.6 & 18.6 & 2.3 & 2.3 & 67.4 & 27.9 & 11.6 & 4.7 & 0 & 7.0 & 39.5 \\
\hline Non-E. coli & 40.6 & 75.4 & 7.2 & 15.9 & 7.2 & 10.1 & 66.7 & 26.1 & 8.7 & 4.4 & 2.9 & 4.3 & 58.0 \\
\hline Klebsiella spp. & 47.8 & 70.0 & 0.0 & 8.7 & 4.3 & 8.7 & 73.9 & 21.7 & 4.3 & 0.0 & 4.3 & 0.0 & 60.9 \\
\hline C. freundii & 33.3 & 88.9 & 3.7 & 18.5 & 0.0 & 11.1 & 70.4 & 25.9 & 11.1 & 3.7 & 0.0 & 11.1 & 66.7 \\
\hline Enterobacter spp. & 41.7 & 58.3 & 16.7 & 0.0 & 16.7 & 16.7 & 25.0 & 0.0 & 8.3 & 8.3 & 8.3 & 0.0 & 25.0 \\
\hline S.marcesens & 42.9 & 71.4 & 28.6 & 57.1 & 28.6 & 0.0 & 100 & 85.7 & 14.3 & 14.3 & 0.0 & 0.0 & 71.4 \\
\hline Site $1 \mathrm{KwaDlangezwa}$ & 38.1 & 85.7 & 14.3 & 14.3 & 9.5 & 4.7 & 66.7 & 28.6 & 4.8 & 0 & 4.8 & 4.8 & 52.4 \\
\hline E. coli & 55.6 & 88.9 & 11.1 & 22.2 & 0 & 0 & 55.6 & 33.3 & 0 & 0 & 0 & 11.0 & 44.4 \\
\hline Non-E. coli & 25.0 & 83.3 & 16.7 & 8.3 & 16.7 & 8.3 & 75.0 & 25.0 & 8.3 & 0 & 8.3 & 0 & 58.3 \\
\hline Site 2 Dlangubo & 42.3 & 65.4 & 11.5 & 11.5 & 3.9 & 3.9 & 61.5 & 26.9 & 11.5 & 3.9 & 3.9 & 3.9 & 34.6 \\
\hline E. coli & 54.5 & 63.6 & 18.2 & 9.1 & 0 & 0 & 63.6 & 0 & 18.2 & 0 & 0 & 0 & 27.3 \\
\hline Non-E. coli & 33.3 & 66.7 & 6.7 & 13.5 & 6.7 & 6.7 & 60.0 & 46.7 & 6.7 & 6.7 & 6.7 & 6.7 & 40.0 \\
\hline Site 3 RB estuary & 62.5 & 81.3 & 12.5 & 31.3 & 6.3 & 0 & 81.3 & 37.5 & 16.7 & 6.3 & 0 & 6.3 & 76.5 \\
\hline E. coli & 60.0 & 100 & 0 & 60.0 & 0 & 0 & 80.0 & 80.0 & 0 & 0 & 0 & 20.0 & 80.0 \\
\hline Non-E. coli & 66.7 & 75.0 & 16.7 & 25.0 & 8.3 & 0 & 83.3 & 33.3 & 25.0 & 8.3 & 0 & 0 & 75.0 \\
\hline Site 4 Mhlathuze station & 40.9 & 63.6 & 4.5 & 18.2 & 4.5 & 9.1 & 77.3 & 13.6 & 9.1 & 4.5 & 0 & 9.1 & 63.3 \\
\hline E. coli & 42.9 & 57.1 & 14.3 & 28.6 & 14.3 & 0 & 85.7 & 28.6 & 28.6 & 14.3 & 0 & 0 & 42.9 \\
\hline Non-E. coli & 40.0 & 66.7 & 0 & 13.3 & 0 & 13.3 & 73.3 & 6.7 & 0 & 0 & 0 & 13.3 & 73.3 \\
\hline Site 5 Felixton & 42.1 & 73.7 & 0 & 15.8 & 0 & 10.5 & 78.9 & 36.8 & 10.5 & 10.5 & 0 & 5.3 & 68.4 \\
\hline E. coli & 20.0 & 40.0 & 0 & 0 & 0 & 0 & 80.0 & 40.0 & 0 & 20.0 & 0 & 0 & 40.0 \\
\hline Non-E. coli & 50.0 & 85.7 & 0 & 21.4 & 0 & 14.3 & 78.6 & 35.7 & 14.3 & 7.1 & 0 & 7.1 & 78.6 \\
\hline
\end{tabular}

A, ampicillin; P, penicillin; T, tetracycline; S, streptomycin; CXM, cefuroxim; NA, nalidixic acid; RIP; rifampicin; KF, cephalothin; TS, co-trimoxazole; NO, novobiocin; C, chloramphenicol; CTX, cefotaxime; FOX, cefoxitin. All isolates were sensitive to the presence of gentamicin and ciprofloxacin.

amongst different sites. However, there were some discrepancies. The isolates from KwaDlangezwa had a higher level of resistance against penicillin. With the exception of cefotaxime and nalidixic acid, the enteric bacteria isolated from the Richards Bay estuary showed a higher level of resistance towards other types of antibiotics. The enteric bacteria isolated from Dlangubo, which is about $40 \mathrm{~km}$ upstream, possessed a generally lower level of resistance. Microbes resistant to nalidixic acid, novobiocin, chloramphenicol and rifampicin were mainly isolated from downstream (Sites 3 to 5; after Felixton). Microbes resistant to tetracycline, cefotoxime and cefuroxin were mainly isolated from upstream (Sites 1 and 2).

\section{Resistance of $E$. coli compared to other Enterobacteriaceae genus}

Table 3 also shows the percentage of each Enterobacteriaceae genus/species which was resistant to each tested antibiotic for the period February 2001 to January 2002. S. marcesens isolates showed a significantly higher level of antibiotic resistance against tetracycline, streptomycin, cefuroxin, cephalothin, novobiocin, chloramphenicol and $100 \%$ resistance against rifampicin. Enterobacter isolates were mostly resistant to nalidixic acid and cefotaxime, but were less resistant against most of the antibiotics tested.

\section{Comparison of ARPs of Enterobacteriaceae isolates from the Mhlathuze River and of clinical isolates from the diarrhoeal patients in this area}

When comparing the ARPs of the environmental isolates from this study with those of the clinical isolates from the diarrhoeal patients near the University of Zululand (Biyela, 2000) as shown in Table 4 , the resistance patterns from both isolates are strongly correlated $(r=0.97)$. Despite the relationship, the clinical isolates exhibited higher resistance against most of the antibiotics tested. 
TABLE 4

A comparison of antibiotic resistance patterns of environmental isolates, isolates with resistance to heavy metals and clinical diarrhoeal isolates

\begin{tabular}{|c|c|c|c|c|c|c|c|c|c|c|c|}
\hline Antibiotic (\%) & A & $\mathbf{P}$ & $\mathbf{T}$ & S & CXM & NA & C & CTX & CIP & KF & GTA \\
\hline $\begin{array}{l}\text { Environmental isolates } \\
\text { Total isolates } \\
\text { E. coli }\end{array}$ & $\begin{array}{l}43.6 \\
46.5\end{array}$ & $\begin{array}{l}72.6 \\
69.8\end{array}$ & $\begin{array}{c}9.4 \\
11.6\end{array}$ & $\begin{array}{l}16.2 \\
18.6\end{array}$ & $\begin{array}{l}5.1 \\
2.3\end{array}$ & $\begin{array}{l}6.8 \\
2.3\end{array}$ & $\begin{array}{l}4.3 \\
4.7\end{array}$ & $\begin{array}{c}1.7 \\
0\end{array}$ & $\begin{array}{l}0 \\
0\end{array}$ & $\begin{array}{l}26.6 \\
27.9\end{array}$ & $\begin{array}{l}0 \\
0\end{array}$ \\
\hline Clinical isolates* & 75 & 80 & 17 & 16.9 & 16.9 & 18.3 & 4.2 & 1.4 & 2.8 & nd & 1.4 \\
\hline $\begin{array}{l}\text { Heavy metal-resistant } \\
\text { isolates } \\
\text { E. coli } \\
\text { Pseudomonas spp. } \\
\text { Bacilius spp. }^{+}\end{array}$ & $\begin{array}{l}\text { nd } \\
\text { nd } \\
\text { nd }\end{array}$ & $\begin{array}{c}71.4 \\
100 \\
83.3\end{array}$ & $\begin{array}{l}57.1 \\
83.3 \\
50.0\end{array}$ & $\begin{array}{c}28.6 \\
16.7 \\
0\end{array}$ & $\begin{array}{l}\text { nd } \\
\text { nd } \\
\text { nd }\end{array}$ & $\begin{array}{l}57.1 \\
83.3 \\
66.7\end{array}$ & $\begin{array}{c}14.3 \\
100 \\
50.0\end{array}$ & $\begin{array}{l}\text { nd } \\
\text { nd } \\
\text { nd }\end{array}$ & $\begin{array}{l}0 \\
0 \\
0\end{array}$ & $\begin{array}{c}71.4 \\
100 \\
83.3\end{array}$ & $\begin{array}{c}0 \\
16.7 \\
0\end{array}$ \\
\hline
\end{tabular}

Abbreviation: See Table 1; CIP: ciprofloxacin; GTA: gentamicin.

* Biyela PT (2000)

${ }^{+}$E. coli, Bacilius spp. and Pseudomonas spp. isolates from the nutrient agar plates with heavy metal.
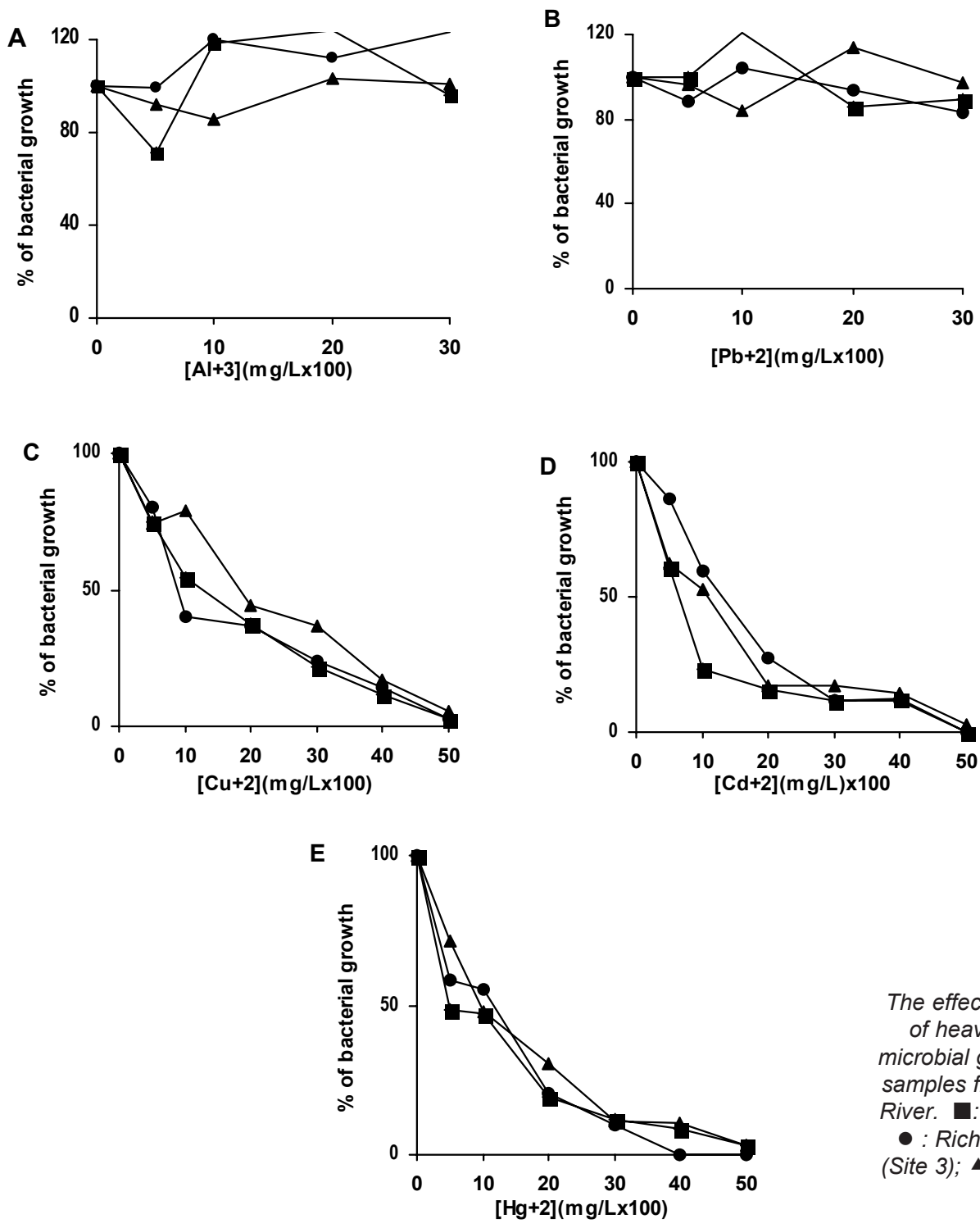

Figure 1

The effects of the presence of heavy metals on the microbial growth of the water samples from the Mhlathuze River. D: Dlangubo (Site 2);

- : Richards Bay estuary (Site 3); $\mathbf{\wedge}$ : Felixton (Site 5) 


\section{The effects of the presence of heavy metals on microbial growth in water samples}

At the concentration of $0.05 \mathrm{mg} \cdot \ell^{-1}$ of $\mathrm{Hg}^{+2}, \mathrm{Cd}^{+2}$ and $\mathrm{Cu}^{+2}$, the growth of microbes in the Mhlathuze River was inhibited up to $50 \%$ and only one or two colonies survived in each plate when the concentrations of the above metals reached $0.5 \mathrm{mg} \cdot \ell^{-1}$. The presence of $\mathrm{Pb}^{+2}$ and $\mathrm{Al}^{+3}$ (up to $0.5 \mathrm{mg} \cdot \ell^{-1}$ ) generated little impact (Fig. 1 A-E). The pattern of microbial growth was unaffected by site. Several Gram-positive (6 Bacilius spp. and 3 Staphylococci spp.) and Gram-negative micro-organisms ( 7 E. coli, 6 Pseudomonas spp., 3 Enterococci and 2 Proteus spp.) were isolated from the media containing high concentrations of heavy metals $\left(\mathrm{Hg}^{+2}, \mathrm{Cd}^{+2}\right.$ and $\mathrm{Cu}^{+2}$ ).

The ARPs of these isolates are shown in Table 4. The ARPs of Enterobacteriaceae isolates from the Mhlathuze River as well as the clinical isolates from the diarrhoeal patients in this area are also included. Most micro-organisms isolated, especially Pseudomonas, from the media with high concentrations of heavy metals exhibited greater resistance against the antibiotics tested. Gentamicin and ciprofloxacin were found to be the most potent antibiotics to inhibit the growth of micro-organisms.

\section{Discussion}

The ARPs of the enteric bacteria isolated from the Mhlathuze catchment, showed that $94.7 \%$ of these isolates were resistant to at least one class of antibiotics. Multi-resistance was very common amongst these isolates (Table 2). Compared to Park et al. (2003) who showed that $53.6 \%$ of coliform isolates were resistant to one or more antibiotics tested, a larger proportion of microbes in the Mhlathuze River was resistant to antibiotics.

The ARPs of the Mhlathuze isolates were similar regardless of the site. E. coli and non-E. coli isolates also showed similar ARPs. (Table 3) The results indicated that micro-organisms with antibiotic resistance were widespread in the Mhlathuze catchment. High levels of antibiotic resistance by all isolates against penicillin, ampicillin and cephalothin indicated that the $\beta$-lactamase gene may be widely present in the gene pool of microbes in this environment.

Some discrepancies of ARPs emerged from our results. The enteric bacteria isolated from Dlangubo (Site 2), which is about 40 $\mathrm{km}$ upstream, exhibited a generally lower level of resistance. Microbes resistant to nalidixic acid, novobiocin, chloramphenicol and rifampicin were mainly isolated from downstream (Sites 3 to 5). Microbes (non-E. coli) resistant to cefotoxime and cefuroxin were mainly isolated from upstream. Several reports have demonstrated the effects of heavy metals and industrial effluent on the antibiotic resistance distribution of bacterial isolates. Several heavy metals were detected in Felixton (Site 5) and Richards Bay estuary (Site 3) (Lin et al., 2004a). The Richards Bay estuary (Site 3) is located in the brackish water environment near aluminium smelters and the fertiliser manufacturing factories. Felixton (Site 5) hosts a sugar mill and paper pulping factories as well as agricultural and informal farming activities. The enteric bacteria isolated from these sites showed a higher level of resistance against several antibiotics compared to those from other sites. Resistance to rifampicin also prevailed in the downstream (Table 3; Sites 3 to 5). The lower level of resistance to antibiotics around Dlangubo (Site 2) suggests that environmental, industrial and/or human activities may impact on the microbial activity in the Mhlathuze River.

The presence of heavy metals in the environment is affecting the microbial growth and poses a public health risk (Goñi-Urriza et al., 2000; Nies, 1999). The ARPs of bacterial isolates indicate that these isolates, especially Pseudomonas spp., possessing the ability to survive in the high concentrations of heavy metals, are also better equipped to resist the presence of antibiotics (Table 4).

The strong correlation $(r=0.97)$ between the ARPs of the clinical and the environmental isolates (Table 4) may suggest a link between diarrhoeal incidence and the water quality in the region. The high resistance of Enterobacteriaceae isolates to rifampicin in this study coincides with the high resistance of Mycobacterium tuberculosis isolated from TB patients in this region to the same antibiotic (19.3\%) (Lin et al., 2004b). Our findings of higher levels of antibiotic resistance amongst the clinical and heavy-metal resistant isolates compared to those in the environmental isolates (Table 4) may support the idea that sustained pressures like antibiotics and/or industrial effluents may enhance the ability of microbes to resist the presence of antibiotics/drugs (McArthur and Tuckfield, 2000; ASM Colloquium Report, 1999).

With poor sanitation facilities and unavailability of infrastructure to supply drinking water, the high levels of faecal contamination together with the high levels of multiple antibiotic resistance amongst the isolated enteric bacteria are a major cause for concern. This is likely to have serious consequences for health care management and prevention within the local communities (Lo Presti et al., 2000; White et al., 2000).

\section{Conclusion}

High levels of antibiotic resistance of the enteric bacteria isolated from the Mhlathuze River were observed. Multi-resistance patterns to antibiotics were common amongst the isolates. Our results indicate that the industrial and human activities might contribute to this phenomenon. The antibiotic resistance gene pool especially $\beta$-lactamase may be widely available in this Mhlathuze Catchment area. It is thus imperative that the determination of antibiotic susceptibility/resistance patterns of isolated microbes be a part of the microbial monitoring process. The observations should be closely correlated with disease management practices and other possible factors that may contribute to antibiotic resistance (Harwood et al., 2000).

\section{Acknowledgment}

The project leader wishes to thank the National Research Foundation (GUN 2038429) and the Water Research Commission (K5/ 1282) for the financial support of this study.

\section{References}

ASH RJ, MAUCK B and MORGAN M (2002) Antibiotic resistance of gram-negative bacteria in rivers, United States. Emerging Infect. Dis. 8 (7) $713-716$

ASM COLLOQUIUM REPORT (1999) Antimicrobial Resistance, An Ecological Perspective. American Society for Microbiology, Washington DC, pp. 1-14.

BALAGUÉ C and GARCÍA-VÉSCOVI E (2001) Activation of multiple antibiotic resistance in uropathogenic Escherichia coli strains by aryloxoalcanoic acid compounds. Antimicrob. Agents Chemother. 45 1815-1822.

BEZUIDENHOUT C, MTHEMBU N, PUCKREE T and LIN J (2002) Microbiological evaluation of the Mhlathuze River KwaZulu-Natal (RSA). Water SA 28 (3) 281-286.

BIYELA PT (2000) A Study of Causes of Diarrhoea in the Northern KwaZulu-Natal. Honours Dissertation, University of Zululand.

DAVIDSON J (1999) Genetic exchange between bacteria in the environment. Plasmid 42 73-91. 
DEPAOLA A, PEELER J and RODRICK GE (1995) Effects of oxytetracycline-mediated feed on antibiotic resistance of Gram-negative bacteria in catfish ponds. Appl. Environ. Microbiol. $612335-2340$.

EDLUND C, BJORKMAN L, EKSTRAND J, SADBORGH-ENGLUND $G$ and NORD CE (1996) Resistance of the normal human microflora to mercury and antimicrobials after exposure to mercury from dental amalgam fillings. Clin. Infect. Dis. 22 944-950.

GOÑI-URRIZA M, CAPDEPUY M, ARPIN C, RAYMOND N, CAU METTE P and QUENTIN C (2000) Impact of an urban effluent on antibiotic resistance of riverine Enterobacteriaceae and Aeromonas spp. Appl. Environ. Microbiol. 66 (1) 125-132.

HARWOOD VJ, WHITLOCK J and WITHINGTON V (2000) Classification of antibiotic resistance patterns of indicator bacteria by discriminant analysis: Use in predicting the source of fecal contamination in subtropical waters. Appl. Environ. Microbiol. 66 (9) 3698-3704.

LIN J, BIYELA PT, PUCKREE T and BEZUIDENHOUT CC (2004a) A study of the water quality of the Mhlathuze River, KwaZulu-Natal (RSA): Microbial and Physico-chemical factors. Water $S A \mathrm{Vol}+\mathrm{No}$ to be followed.

LIN J, MVELASE TP, PUCKREE T and SHATTER AN (2004b) Alarming Rate of Drug Resistant Tuberculosis at the Ngwelezane Hospital in the Northern KwaZulu Natal, South Africa. Int. J. Tuberc. Lung Dis. In press.

LO PRESTI F, RIFFARD S, JARRAUD S, LE GALLOU F, RICHET H, VANDENESCH F and ETIENNE J (2000) Isolation of Legionella oakridgensis from two patients with pleural effusion living in the same geographical area. J Clin. Microbiol. 38 (8) 3128-3130.

McARTHUR JV and TUCKFIELD RC (2000) Spatial Patterns in Antibiotic Resistance among stream bacteria: Effects of industrial pollution. Appl. Environ.Microbiol. 66 (9) 3722-3726.

MIDIGAN MT, MARTINKO JM and PARKER J (2003) Brock: Biology of Microorganisms (10 ${ }^{\text {th }}$ edn.). Chapter 19, Pearson Education Inc., Prentice Hall. 673-674.
NCCLS (2000) Performance Standards for Antimicrobial Disk Susceptibility Tests. NCCLS document M2-A7. Wayne, PA: National Committee for Clinical Laboratory Standards.

NIES DH (1999) Microbial Heavy-MetalRresistance, Molecular Biology and Utilisation for Biotechnology. Institute für Mikrobiologie, Martin-Luther Univerisital, Hall-Wittenberg, Kurt-Mothers St. 730-750.

OGAN MT and NWIIKA DE (1993) Studies on the ecology of aquatic bacteria of the lower Niger Delta: Multiple antibiotic resistance among the standard plant count organisms. J. Appl. Bacteriol. 74 595-602.

PARK JC, LEE JC, OH JY, JEONG YW, CHO JW, JOO HS, LEE WK and LEE WB (2003) Antibiotic selective pressure for the maintenance of antibiotic resistant genes in coliform bacteria isolated from the aquatic environment. Water Sci. Technol. 47 (3) 249-253.

STANDARD METHODS (1998) Standard Methods for the Examination of Water and Wastewater. Clesceri LS, Greenberg AE and Eaton AD (eds.). American Public Health Association, $20^{\text {th }}$ Edition, Washington DC.

STEYL I, VERSFELD DB and NELSON PJ (2000) Strategic Environmental Assessment for Water Use: Mhlathuze Catchment KZN. DWAF Report No SEA-01/2000.

WHO (2000) Global Surveillance of Epidemic-prone Infectious Diseases. Chapter 4: Cholera. World Health Organization. WHO/CDS/CSR/ ISR/ 2000.

WHO (1996) Epidemic Dysentery. Fact sheet No 108, pp. 1-2. http:// www.who.int/inf-fs/en/fact108.html.

WHITE DG, PIDDOCK LJV, MAURER JJ, ZHAO S, RICCI V and THAYER SG (2000) Characterization of fluoroquinolone resistance among veterinary isolates of avian Escherichia coli.J. of Antimicrobiol. Agents Chemother. 44 (10) 2897-2899.

WILKINSON L (1988) Systat:The System for Statistics, Evanston Systat. 